\title{
RELATIONSHIP BETWEEN PRODUCTIVITY AND DIGITALIZATION WITH TOBIT MODEL BASED ON MALMQUIST INDEX
}

\author{
Eda BOZKURT ${ }^{1}$, Özlem TOPÇUOĞLU², Ali ALTINER ${ }^{3}$
}

\section{ABSTRACT}

Purpose: The sources of economic growth include capital, labor and the Solow surplus, dedicated to the study of Solow (1956). Solow surplus is the inexplicable part of growth with labor and capital and is expressed as technological advances. Solow surplus also means total factor productivity (TFP). In other words, economic growth is explained by TFP depending on technology from the past to the present. These days, digitalization is known to be the new technological revolution. In light of this concept, the study aims to demonstrate the impact of digitalization on TFP.

Methodology: A TFP calculation based on the Malmquist index was made using labor, capital and gross domestic product data for 30 countries in the period 2012-2020. The Tobit Panel estimate was then used to determine the effect of digitalization on TFP in the relevant period.

Findings: the results of the panel estimate are that digitalization has a significant and positive impact on TFP. The findings suggest that digitalization contributes to productivity.

Originality: The most important feature that distinguishes research from studies in the literature is that a verification method is selected that uses real data. In addition, works covering many countries in literature is limited. The research has results from a multi-country perspective.

Keywords: Digitalization, Malmquist Index, Tobit Model, Productivity.

JEL Codes: C23, O4, O14.

\section{MALMQUIST ENDEKSE DAYALI TOBIT MODEL İLE VERIMLILIKK VE DİJITALLEŞME İLişKisi \\ ÖZET}

Amaç: İktisadi büyümenin kaynakları arasında sermaye, emek ve Solow'un (1956) çalışmasına ithafen Solow Artığı yer almaktadır. Solow Artığı büyümenin emek ve sermaye ile açıklanamayan kısmı olup teknolojik ilerlemeler olarak ifade edilmektedir. Solow Artığı aynı zamanda toplam faktör verimliliği (TFV) demektir. Yani geçmişten günümüze ekonomik büyüme teknolojiye bağlı olarak TFV ile açıklanmaktadır. Bugünlerde dijitalleşmenin yeni teknolojik devrim olduğu bilinmektedir. İşte bu konsept ışığında çalışmada dijitalleşmenin TFV'ye etkisini ortaya koymak amaçlanmıştır.

Yöntem: 2012-2020 döneminde 30 ülke için emek, sermaye ve gayrisafi yurtiçi hasıla verilerinden faydalanılarak Malmquist Endekse dayalı TFV hesaplaması yapılmıştır. Daha sonra ilgili dönemde digitalleşmenin TFV'ye etkisini tespit etmek için Tobit Panel tahmini yapılmıştır.

Bulgular: Panel tahmin sonuçları dijitalleşmenin TFV'yi anlamlı ve pozitif yönde etkilediği yönündedir. Bulgular dijitalleşmenin verimliliğe katkı sağladığını göstermektedir.

Özgünlük: Araştırmayı literatürdeki çalışmalardan ayıran en önemli özellik gerçek verilerin kullanıldığı bir doğrulama yönteminin seçilmiş olmasıdır. Ayrıca ilgili yazında birçok ülkeyi ele alan çalışma sınırlı sayıdadır. Araştırma çok ülke açısından sonuçlar barındırmaktadır.

Anahtar Kelimeler: Dijitalleşme, Malmquist Endeksi, Tobit Model, Verimlilik.

JEL Kodları: C23, O4, O14.

\footnotetext{
1 Assoc. Prof., Atatürk University, Faculty of Open Education, Department of Foreign Trade, Erzurum, Turkey, edabozkurt@atauni.edu.tr, ORCID: 0000-0001-7158-8049 (Corresponding Author).

${ }^{2}$ Asst. Prof, Atatürk University, Vocational School of Social Sciences, Department of Foreign Trade, Erzurum, Turkey, ozlemgunduz@atauni.edu.tr, ORCID: 0000-0002-9821-5856.

${ }^{3}$ Assoc. Prof., Recep Tayyip Erdoğan University, Faculty of Economics and Administrative Sciences, Department of Economics, Rize, Turkey, ali.altiner@erdogan.edu.tr, ORCID:0000-0001-7362-8198.
} 


\section{INTRODUCTION}

One of the most widely studied assumptions of economic theory is homo economicus. Classical and neoclassical economists claim that man is a homo economicus. Homo economicus meets the concept of economic man with its best-known definition. Economic man pursues personal interests. In economic jargon, as consumers people aim to maximize benefits and well-being. Although the rational assumption of man acting rationally continues to be debated in the economic literature, it is certain that man seeks to live comfortably, away from grief. Inventions and discoveries that have emerged throughout history have always served to facilitate the life of mankind. In the early ages, while man lived on the run from predators, he rose to ecological leadership and took control of life, putting an end to human weakness with the discovery of fire. Later, he invented the wheel and thus discovered the ease of carrying both the animals he hunted and other loads. Compass, printing press, gunpowder, microscope, steam machine, electricity and many other innovations have emerged as a result of human experience. No doubt, the first step of science and technology was taken with the Industrial Revolution. In the $18^{\text {th }}$ century machines replaced muscle power. In the $19^{\text {th }}$ and $20^{\text {th }}$ centuries, integral parts of life such as cars, airplanes, radio, television, computers were discovered with modern scientific applications. Second industrial revolution was replaced by the third industrial revolution with radical technological changes at the end of the $20^{\text {th }}$ century. As the concept of information and communication technologies entered our lives in the $21^{\text {st }}$ century, artificial intelligence brought with it new concepts such as the Internet of things. Here, digitalization is also among the most decidedly spoken words of this century.

There's always something that comes to everyone's mind about what digitalization is. Manufacturers, companies, suppliers, consumers and states have been designing their policies and behaviors according to the next generation of technology for several decades. Production, distribution and consumption go beyond traditional methods and are carried out using online methods. Through online shopping portals, consumers can access other consumer experiences related to the products they buy. Shopping is no longer an activity that requires going out. Mobile phones have minimized the world, leaving it in the hands of humanity. Many people start their day by checking their social media accounts. In the '80s or' 90 s, people followed their favorite artists only on television, while young people hung posters of singers or athletes they were fans of by their bedside, this attitude is now considered quite outdated. Watching TV series is also no longer among today's trends. Because the series industry now uses digital platforms. No one on the streets anymore has to ask anyone for the address they are looking for. Applications installed on mobile phones can direct people to their destination without errors. For example, it can create and track nutrition, health and sports identity digitally using a mobile phone. Most people no longer follow the closing time of the banks. Banking operations can be easily done via internet banking without having to go to the branch. The digital world offers people much more than that. It has become possible to go to Sanlıurfa in a few minutes with virtual tours and to visit Göbeklitepe ruins. Similarly, connecting to the world's most famous museums, exhibitions or concerts is one of the blessings of the digital world decisively. Given the presence of a global pandemic in recent days, a lifestyle has been formed in which people work from home and students are allowed to study distantly. Over the past two years, closure processes in countries to reduce the risk of transmission of the outbreak have shown that the reality of digitalization is inevitable.

Although digitalization seems to be developing rapidly because it facilitates social life, it is believed that the main factor that increases digitalization is the economy. Because digitalization provides great potential in growing economies and creating opportunities. Although the effect of digitalization on improving economic well-being is found attractive by many, in fact, the adoption of digitalization varies from business to business. Digitalization practices can vary decidedly between sectors in terms of ratio and scope. While the possibility of digitalization is largely dependent on industry, the local economic situation is known as an important parameter. But still, the known fact is that digitalization is a concept applied to increase efficiency and reduce costs (Leon and Meyer, 2019).

Everyone agrees that our planet is undergoing a rapid digital transformation. So, what is the outcome as the world becomes more digitized? Can habit turn into addiction or even slavery? Is digital power beneficial or harmful? The main motivation of our research is whether digitalization contributes to economic productivity. Therefore, digitalization has been studied conceptually as a priority. An answer to how digitalization is measured was then sought to determine the true effect of digitalization. Then, the effect of digitalization on economic productivity was examined in 2012-2020 period by Tobit Panel Data Analysis for 30 countries. TFP has been calculated to perform Panel data analysis. Possible contributions of the study to the literature can be listed as:

- It is aimed to provide conceptual recognition by providing a detailed study of digitalization at a theoretical level. 
- $\quad$ Productivity calculation was made by based on the Malmqusit TFP Index. In this way, issues such as what productivity is and how it is calculated are also included in the research.

- It is noteworthy that there are few studies investigating the effect of digitalization on productivity in literature scanning. In particular, the research based on econometric techniques remains quite limited. It was intended to expand the analysis-based literature.

- Finally, unlike the article in question of digitalization, it is aimed to reveal a total productivity effect by examining not only the size of labor productivity, but also the size of capital.

\section{THEORETICAL BACKGROUND and LITERATURE}

It is not easy to draw any frame to "What is digitalization?" question given the unlimited human needs. Some terms are used interchangeably on issues related to digitalization, causing concept confusion. In literature, digitization, digitalization, and digital transformation are the most commonly used words. In particular, digitization and digitalization are quite confused due to the two-letter difference. In fact, the difference between these two concepts is decidedly more than a matter of letters (Savic, 2019).

Digitization refers to the conversion of information from physical format to digital format. For example, digitization is the process of scanning a contract, creating it as a PDF, and saving it to drive C. Digitalization, on the other hand, is the use of digitization to improve processes. Scanning an agreement, creating it as a PDF, and uploading it to the cloud ensures that you can reach this agreement from anywhere and anytime. This is an example of digitalization. Digital transformation, in short, is the effect caused by the digitalization process and to do things digitally again. More effective organizations, efficient service and satisfaction with rapidly developing information and communication technologies in the face of changing social needs, and the change that occurs in business processes are recognized as digital transformation. In fact, digital transformation is seen as a social phenomenon and a cultural evolution. (Leon and Meyer, 2019; Burkett, 2017; Henriette et al., 2016). The increasing popularity of digitalization, especially in the last decade, has pushed researchers and institutions to work in this field. At this point, various definitions related to digitalization have been put forward.

Regarding digitalization Hagberg et al. (2016) implies facilitating new forms of value creation. According to Katz, digitalization is a process of largely adopting information communication technologies to produce, process, and share information (Katz et al., 2013). Bhatnagar (2017) argues that the word digital means the use of binary numbers and that digitalization involves the adoption of this technology and the conversion of physical data into digital format (Bhatnagar, 2017). The International Energy Agency (IEA) deconstructs digitalization as the increasing interaction and convergence between the digital and physical worlds (IEA, 2017). The Ministry of Science, Industry and technology defines digitalization as "a process in which industrialists, employees, universities and the public are transformed and new business models and ways of doing business are created" in the Roadmap of the Industrial Revolution of digital Turkey (2018).

The common idea of the definitions is that digitalization is based on the use of digital technologies. Digital technologies include the Internet of things, social media, artificial intelligence, big data, cloud decks and mobile applications.

Another question that every actor in the economy is looking for an answer to is the extent to which digitalization occurs. Individuals, companies and institutions are making efforts to measure and increase digitalization, which is one of the most important sources of productivity growth. Since indicators in digitalization are very important for policy design, various indices are prepared by different international and national institutions, both economically and technologically. Some of these indices can be listed as follows (IT Industrialists Association-TÜBISAD, 2020; Pakdemirli, 2019)

- Information Communication Technologies Development Index prepared by United NationsInternational Telecommunications Union (ITU),

- The Networked Readiness Index, designed by the World Economic Forum (WEF),

- Digital Economy and Society Index (DESI)prepared by the European Commission,

- Information and Communication Technology Development Indicators prepared by the United Nations Conference on Trade and Development (UNCTAD),

- Cámara and Tuesta (2016) Digitization Index (DiGiX),

- Among the indices of Turkish origin are the Accenture Digitalization Index calculated in 2015 and the Digital Transformation Index of Turkey presented by TÜBISAD in 2020. 
The above-mentioned indices have various data sources and measurement methods and provide data for a specific year's period. Because some indices have not been calculated in recent years, researchers also make digitization measurements based on the survey method. Data is routinely collected and studies continue to be carried out in international databases to produce new indicators (Organization for Economic Co-operation and Development-OECD, 2020). To summarize, we cannot mention a single indicator with respect to digitalization measurement.

Despite the difficulties in the identification and measurement of digitalization, the economy and the ongoing digital transformation of society, encourage innovation, productivity improvement and welfare, besides it has the potential to improve services and increase sustainable and more inclusive growth (Pilat and Criscuolo, 2018; Ezrachia and Stucke, 2018). In particular, the idea that digitalization will give economies momentum with productivity growth is open to debate. In general, productivity refers to how much output is provided by the inputs at hand, that is, the relationship between the output produced by a production or service system and the input used to achieve this output (Coelli et al., 2005; Prokopenko, 2005). How rational the inputs used in the production of an output are used is determined by the concept of productivity. An increase in productivity values is observed if output is produced at the same level as less input, more output is produced without changing the amount of input, more output is produced using less input, more output is generated when there is an increase in inputs, and less output is decreased when there is a decrease in the amount of input.

When the factors affecting productivity are examined, it is seen that researches focus on economic factors generally. But it is known that economic variables alone cannot be sufficient to explain productivity. Economic factors, as well as social, demographic, geographic and even psychological factors, are known to influence productivity. Among these factors, national and international policies, macroeconomic factors, financial opportunities of the firms, management decisions, labor, competition and decency of technology are counted. Digitalization, which is a new form of use of technology, is also considered among the parameters that affect productivity, as mentioned above. Furthermore, the influence of innovation or technology in the economic literature is based on the Schumpeterian hypothesis. In Schumpeter's view, economic events are formed with the entrepreneur emerging from innovation and technical progress. The economic transformation created by digitalization should also be seen as a result of the innovation process based on information technologies. These technologies are constantly and irreversibly reshaping today's economy. Digitalization seems to have the ability to expand, replicate and intensify the entrepreneurial function (Corduneanu, 2018). After Scumpeter, Solow (1956) proposed the Neo-classical theory of growth that economic development is formed by an external factor expressed as physical capital, labor, and technological change. It is accepted that the growth rate in the stationary state is determined externally in the production function. Therefore, according to neoclassical theory, the only factor that provides economic growth is the technological change that occurred by chance and is referred to as the Solow surplus (Solow 1956). According to Mankiw (2003), increased living standards can only be explained by technological improvement according to the Solow model. In new generation studies like Kravchenko et al. (2019), Mammadli and Klivak (2020), Habibi and Zabardast (2020) etc., variable, which represents technological progress that causes economic growth is used as digitalization. It is assumed that digitalization has an effect on yield with the size of supply and demand. From the supply side, production activities are formed by directly entering information into the production of goods and services. Thus, productivity increases and hence income increases. Investment in digital technologies, combined with Labor, constitutes a capital input that leads to deepening capital and increased labor productivity in other sectors of the economy. Digitalization contributes to economic growth through demand by means of the development of human capital achieved through education, training and better health care. Thus, positive externalities are formed that contribute to overall economic growth. For example, the proliferation of mobile phones in developing countries may facilitate long-distance communication, although states have little or no investment in fixed telecommunications infrastructure (Myovella, et al. 2020). But these opportunities may not happen automatically. Some policy actions are needed for digitalization to increase growth and prosperity. Because it is accepted that the opportunities brought by digitalization have negative effects on productivity. Despite the rapid rise of digital technologies that began in the mid-1990s, overall productivity growth is thought to have slowed over the past decade. Thus, there is a serious discussion about the potential of digital technologies to increase productivity. Even Solow said of digitalization, "you can see the computer age everywhere except productivity statistics" in his statements. This fact points out a paradox between technological change and decelerating productivity growth (Pilat and Criscuolo, 2018). Trying to size up the wave of digitalization is no easy task. Because digitalization offers significant opportunities to increase productivity, it also brings migration costs, as well as delay effects and adoption barriers. In other words, the short-term impact of digitalization on productivity can be considered uncertain. But today, companies have a direct impact on output and productivity growth, it is known that the changes that devotes significant time and resources (McKinsey Global Institute, 2018). In the literature studies presented below, it is seen 
that the relationship between digitalization and productivity shows decidedly different results. For example; Jacobsen et al. (2011) examined digitization and firm productivity in Danish firms for 2008 and 2009 in their analysis based on a survey. The findings showed that digitalization has a strong positive correlation with productivity. It was determined that the percentage increase in the probability of digitization of a firm resulted in a $0.72 \%$ increase in value added per employee.

Gal et al. (2019) examined the link between the least squares (OLS) method and firm-level digitalization productivity in 20 countries during $2010-2015$ years. The results showed that there is no productivity paradox. Horvat et al. (2019) examined the impact of automation and digitalization on the performance of manufacturing companies in Germany during the 1993-2012 periods. Using surveys from the German Manufacturing survey, they determined that both automation and digitalization had a significant and positive impact on labor productivity by the OLS method. In terms of TFP, they found that only automation had a positive effect. Trasca et al. (2019) examined the impact of digitalization on economic performance in central and Eastern European countries with survey data published by the European Commission in 2018. Productivity and export rate have been seen to improve when digital technologies are integrated into commercial activities. Metlyakhin et al. (2020) examined the main factors of digitalization affecting labor productivity with data covering the period 2006-2017 with static panel data analysis in 77 regions in Russia. In organizations requiring automation, factors such as computerization of workplaces, use of server equipment, mobile subscriber devices and broadband internet connection have been found to significantly affect productivity. Akaev and Sadovnichiib (2021) calculated labor productivity in the digital economy using a mathematical prediction method based on Kondrat'ev's long wave. The authors have suggested that the highest labor productivity will occur in a situation dominated by human labor in the collaboration of human and intelligent machine. They determined that the lowest labor productivity occurred when intelligent machines were dominant. Berlak et al. (2021) examined the productivity impact of digitalization based on event studies in building construction industry in Germany. They determined that digitalization had an impact on productivity. Cette et al. (2021), investigated the impact of digitalization on productivity in French firms with multiple correspondence analysis based on Banque de France 2018 survey data. According to the findings, the use of digital technologies outside the institution increases the firm's labor productivity by about $23 \%$ and the overall factor productivity by about $17 \%$. Within the institution, it has a negative impact of 2.5 percentage on the workforce. Jeske et al. (2021) examined the impact of digitalization on management, productivity and human work in the German metal and electrical industry through surveys conducted in 2015, 2017 and 2019. From the perspectives studied in descriptive analyses, it was found that digitalization in the production industry has made progress and that there are multifaceted digitalization opportunities for companies and employees. Krutova et al. (2021) examined the impact of binomial logistic regression and digitalization on productivity and unemployment in Finland with data from the 2018 Quality of Work Life Survey. The study found that the contribution of traditional factors of production to labor productivity potentially reduces the risk of permanent job loss, and increases the risk of permanent job loss because innovative factors of production negatively affect TFP inputs. Yilmaz (2021) examined the place of Turkey in the digitization process and the effect of digitization on productivity by documentation method in the study. In the study, it was concluded that digitalization will positively affect both total factor productivity and labor productivity. But it has been determined that Turkey has not reached a sufficient level in the process of digitalization.

The literature review shows a limited number of studies examining the relationship between digitalization and productivity. In addition, it can be said that these studies are based on survey data in general, firm or sector-based elections are conducted, lack of multi-country analysis and focus on labor productivity rather than TFP in general.

\section{METHODOLOGY}

In the empirical analysis part of the study, the effect of digitalization on the productivity was investigated for period 2012-2020 for a total of 30 countries including 26 European Union (EU) member (Austria, Belgium, Bulgaria, Croatia, Cyprus, Czechia, Denmark, Estonia, Finland, Germany, Greece, Hungary, Ireland, Italy, Latvia, Lithuania, Luxembourg, Malta, Netherlands, Poland, Portugal, Romania, Slovakia, Slovenia, Spain, Sweden) countries, 1 country for which EU membership process is ongoing (Turkey) and 3 non-EU member European countries (Iceland, Norway, United Kingdom). The data was obtained from the EU statistical agency (Eurostat) and the World Bank database. Because the balanced panel data analysis method was used in the study, countries with discrete data were excluded.

The study consists of two phases. At the first stage, TFP values, which are considered to be one of the most obvious productivity indicators of countries, were calculated for the 30 countries concerned, both in terms of providing information about country performance and for use as a dependent variable in the Tobit model created. The Malmquist TFP Index, a data enveloping analysis (DEA) - based technique, was 
preferred in TFP calculation. The next stage is a panel of Tobit estimates to investigate the impact of digitalization on TFP.

In regression estimation, if all the observation values of the dependent variable are not fully obtained, or if all the values of the dependent variable can be observed but defined within a certain interval, Limited Dependent Variable Models should be used in such models (Şengül et al. 2013). The fact that the dependent variable values (TFP values) used in the study are above 1 indicates that the productivity change has changed in the direction of increase compared to the previous year. For this reason, the Tobit estimate was preferred as a limited dependent variable model in the study, since the dependent variable must be limited.

\subsection{Malmquist Total Factor Productivity Index}

Although the concept of TFP explains the reasons for differences in growth and development in countries, it is also of great importance in terms of determining which factor of production is more effectively included in production as a driving force in the process of determining the sources of growth and development.

TFP and its components have many problems in terms of scalability. In general, productivity measurements are made at the economic, market and business level. Studies conducted at the level of overall economic productivity allow countries to monitor the developments they have put forward over time and conduct an inter-country situation assessment. Productivity can be measured by two approaches in the form of non-frontier approaches and frontier approaches, which are created by taking into account two parametric and non-parametric methods (Oyeranti, 2000). In the study, the Malmquist TFP Index, a nonparametric method included in the frontier approach, was calculated to determine the TFP values of 30 European countries.

The TFP Index reveals the TFP exchange of decision making between the two time ranges. The index describes the progress/decline in total factor productivity with multiple inputs/outputs and the change over time (Tone, 2004). This index was published by Caves et al. (1982) was developed by Sten Malmquist (1953) and is called the Malmquist Index after Sten Malmquist, who first came up with the idea of determining a real number that measures the change in the set formed by variables related to each other using distance functions.

The Malmquist TFP index, a DEA-based approach, measures the change in the total factor productivity of two observations as the ratio of distances to a common technology. Index is formulized according to the definition of Fare et al.'s (1994) geometric mean of the two Malmquist productivity indices $\left(M_{1}\right.$ ve $\left.M_{2}\right)$, as in Equation 1:

$M=\left(M_{1} * M_{2}\right)^{1 / 2}$

$M_{1}$ in the formula represents the Malmquist index obtained based on t period technology, while $\left(M_{2}\right)$ represents the Malmquist index obtained based on $t+1$ period technology. $M$ can take values equal to 1 , greater than 1 , or less than 1 depending on the productivity changes between two periods in the i production unit (Coelli, 1996).

The Malmquist index also provides information on the sources of change in TFP (Equation 2).

$\underbrace{M_{1}^{t+1}\left(y^{t}, y^{t+1}, x^{t}, x^{t+1}\right)}_{T F P C}=\underbrace{\frac{D_{1}^{t}\left(y^{t+1}, x^{t+1}\right)}{D_{1}^{t}\left(y^{t}, x^{t}\right)} *}_{E C} \underbrace{\left[\frac{D_{1}^{t}\left(y^{t+1}, x^{t+1}\right)}{D_{1}^{t+1}\left(y^{t+1}, x^{t+1}\right)} * \frac{D_{1}^{t}\left(y^{t}, x^{t}\right)}{D_{1}^{t+1}\left(y^{t}, x^{t}\right)}\right]^{1 / 2}}_{T C}$

Equation 2 means that the change in total factor productivity (TFPC) expressed by the TFP change consists of multiplying the productivity change (EC) and the technical change (TC). The productivity change shows how close the production unit is to the effective limit, while the technical change shows the effective limit change. When the values obtained are evaluated between $t$ and $t+1$ period, the fact that the result is greater than 1 indicates that the effectiveness and technical change increases, the fact that it is less than 1 decreases, and the fact that it is equal to 1 does not change (Sturm and Williams, 2002).

Since the return characteristics of technology relative to scale have an important place in the TFP index, the assumption of the CCR Model, DEA model that takes constant return relative to scale, should be based on estimating distance functions in the measurement of the Malmquist Index. For this reason, the calculation was made by taking into account CCR values in the analysis. Employment and gross capital formation values of countries were used as input variables in the calculations of the Malmquist TFP index for CCR scores, while gross domestic product values were used as output variables. 


\subsection{Tobit Model}

In econometric analysis, having to limit the value of the dependent variable from the bottom or top causes data loss. In such a case, information about the dependent variable is found only for some observations, such a censored regression model is known as the Tobit Model. The Tobit Model, an extension of the Probit model, was developed by James Tobin (Tobin, 1958).

Linear regression of an observable (latent) dependent variable $\left(\mathrm{y}^{*}\right)$ with independent variable(s) is defined as in Equations 3-5.

$y_{i}^{*}=x_{i}^{\prime} \beta+u_{i} \quad(i=1, \ldots, n)$

$y_{i}= \begin{cases}y_{\mathrm{i}}^{*}, & \mathrm{y}_{\mathrm{i}}^{*}>0 \\ 0, & \mathrm{y}_{\mathrm{i}}^{*} \leq 0\end{cases}$

$u_{i} \sim \operatorname{IIN}\left(0, \sigma^{2}\right)$

Here; $\mathrm{y}_{\mathrm{i}}^{*}$ indicates unobservable (latent) dependent variable, $\mathrm{X}_{\mathrm{i}}$ explanatory variable $(\mathrm{s})$ to the vector, $\beta$ vector of coefficients, $u_{i}$ identical and independent normal distribution (identically and independently Normal IIN) error term and $\mathrm{y}_{\mathrm{i}}$ indicates the observed dependent variable.

At the first stage of the study, the productivity values obtained by the Malmquist TFP Index, a DEAbased measurement, were limited to 1 from the top (from the right). Limiting the TFP values that will be used as dependent variables has led to the most appropriate choice for the model to be created in the second phase of the study being the Tobit Model. The Random Effects Panel Tobit model, created to decipher the relationship between TFP values and digital participation values of 30 countries used in the analysis, is defined as in Equations 6-8.

$$
\begin{aligned}
& y_{i t}^{*}=x_{i t}^{\prime} \beta+u_{i}+\varepsilon_{i t} \\
& y_{i t}=\left\{\begin{array}{c}
y_{i t}^{*}, \quad y_{i t}^{*}<1 \\
1, \quad y_{i t}^{*} \geq 1
\end{array}\right. \\
& u_{i} \sim \operatorname{IIN}\left(0, \sigma_{u}^{2}\right) \text { and } \varepsilon_{i t} \sim \operatorname{IIN}\left(0, \sigma_{\varepsilon}^{2}\right)
\end{aligned}
$$

In the model in which TFP scores are included as dependent variables, the model in which digital participation (dig) values of countries represent digitalization as independent variables are estimated.

The model created as a result of studying both theoretical and practical studies for the purpose of the study is as follows (Equation 9):

$T F P_{i t}=\beta_{0}+\beta_{1}$ DIGINC $_{i t}+u_{i}+\varepsilon_{i t}$

In the model, TFP $i t$ is total factor productivity value of $i$ country in $t$ and $D I G I N C_{i t}$ is digital participation rate of $i$ country in year $t$. In addition, $\mathrm{u}_{\mathrm{i}}$ and $\varepsilon_{\mathrm{it}}$ are the error terms of the model, and $\mathrm{u}_{\mathrm{i}}$ refers to the random effect and is the same in each period.

$T F P_{i t}$ variable used as a dependent variable was calculated by us as the Malmquist TFP Index, which refers to the change in TFP between the two periods, using the employment and gross capital formation values of countries as input variables, and the gross domestic product values as output deciduous variables. Digital inclusion is an EU-wide effort to ensure that everyone can contribute to and benefit from the digital world (European Commission, 2021).

\section{FINDINGS}

Using the DEAP 2.1 program, the TFP indices calculated as of 2012-2020 are reported in Table 1. When the results contained in the chart are evaluated between $t$ and $t+1$ period, the result greater than 1.000 means an increase in TFP, less than 1.000 means deceleration, and equal to 1.000 means that no change has occurred. 
Table 1. Malmquist total factor productivity values

\begin{tabular}{|c|c|c|c|c|c|c|c|c|}
\hline \multirow[b]{2}{*}{ Country } & \multicolumn{8}{|c|}{ Periods } \\
\hline & $\begin{array}{c}2012- \\
2013\end{array}$ & $\begin{array}{c}2013- \\
2014\end{array}$ & $\begin{array}{c}2014- \\
2015\end{array}$ & $\begin{array}{c}2015- \\
2016\end{array}$ & $\begin{array}{c}2016- \\
2017\end{array}$ & $\begin{array}{c}2017- \\
2018\end{array}$ & $\begin{array}{c}2018- \\
2019\end{array}$ & $\begin{array}{r}2019- \\
2020\end{array}$ \\
\hline Austria & 0,518 & 0,682 & 0,763 & 0,810 & 0,841 & 0,864 & 0,881 & 0,899 \\
\hline Belgium & 0,520 & 0,681 & 0,762 & 0,810 & 0,842 & 0,865 & 0,882 & 0,899 \\
\hline Bulgaria & 0,545 & 0,698 & 0,771 & 0,811 & 0,839 & 0,861 & 0,876 & 0,900 \\
\hline Croatia & 0,539 & 0,690 & 0,762 & 0,802 & 0,834 & 0,858 & 0,876 & 0,898 \\
\hline Cyprus & 0,583 & 0,727 & 0,791 & 0,828 & 0,857 & 0,877 & 0,895 & 0,923 \\
\hline Czechia & 0,513 & 0,676 & 0,756 & 0,805 & 0,837 & 0,861 & 0,878 & 0,894 \\
\hline Denmark & 0,517 & 0,680 & 0,760 & 0,808 & 0,840 & 0,863 & 0,880 & 0,896 \\
\hline Estonia & 0,776 & 0,843 & 0,884 & 0,899 & 0,900 & 0,916 & 1,014 & 1,003 \\
\hline Finland & 0,515 & 0,678 & 0,758 & 0,806 & 0,838 & 0,862 & 0,879 & 0,894 \\
\hline Germany & 0,504 & 0,668 & 0,750 & 0,800 & 0,833 & 0,857 & 0,875 & 0,889 \\
\hline Greece & 0,515 & 0,677 & 0,758 & 0,807 & 0,838 & 0,861 & 0,879 & 0,895 \\
\hline Hungary & 0,508 & 0,672 & 0,754 & 0,804 & 0,836 & 0,859 & 0,877 & 0,892 \\
\hline Iceland & 0,588 & 0,705 & 0,777 & 0,820 & 0,852 & 0,872 & 0,890 & 1,026 \\
\hline Ireland & 0,513 & 0,675 & 0,752 & 0,807 & 0,837 & 0,860 & 0,879 & 0,893 \\
\hline Italy & 0,508 & 0,676 & 0,759 & 0,807 & 0,839 & 0,863 & 0,880 & 0,898 \\
\hline Latvia & 0,558 & 0,727 & 0,802 & 0,851 & 0,873 & 0,888 & 0,906 & 1,000 \\
\hline Lithuania & 0,611 & 0,731 & 0,797 & 0,843 & 0,862 & 0,886 & 0,899 & 1,105 \\
\hline Luxembourg & 0,541 & 0,688 & 0,757 & 0,801 & 0,835 & 0,858 & 0,876 & 0,890 \\
\hline Malta & 0,633 & 0,756 & 0,809 & 0,858 & 0,868 & 0,892 & 1,002 & 1,021 \\
\hline Netherlands & 0,517 & 0,679 & 0,761 & 0,809 & 0,840 & 0,863 & 0,880 & 0,896 \\
\hline Norway & 0,519 & 0,681 & 0,762 & 0,811 & 0,842 & 0,865 & 0,882 & 0,896 \\
\hline Poland & 0,519 & 0,681 & 0,760 & 0,809 & 0,839 & 0,861 & 0,878 & 0,894 \\
\hline Portugal & 0,514 & 0,676 & 0,757 & 0,806 & 0,838 & 0,861 & 0,878 & 0,895 \\
\hline Romania & 0,510 & 0,674 & 0,756 & 0,804 & 0,836 & 0,860 & 0,878 & 0,893 \\
\hline Slovakia & 0,506 & 0,671 & 0,753 & 0,803 & 0,835 & 0,859 & 0,877 & 0,891 \\
\hline Slovenia & 0,551 & 0,707 & 0,783 & 0,827 & 0,853 & 0,874 & 0,891 & 1,089 \\
\hline Spain & 0,514 & 0,676 & 0,756 & 0,805 & 0,837 & 0,861 & 0,878 & 0,896 \\
\hline Sweden & 0,519 & 0,681 & 0,760 & 0,809 & 0,840 & 0,863 & 0,881 & 0,896 \\
\hline Turkey & 0,514 & 0,677 & 0,758 & 0,807 & 0,838 & 0,862 & 0,880 & 0,893 \\
\hline United Kingdom & 0,506 & 0,672 & 0,755 & 0,804 & 0,837 & 0,860 & 0,878 & 0,894 \\
\hline
\end{tabular}

Considering the values reported in Table 1 in the period 2018-2019 only Estonia and Malta exhibited increased productivity compared to the previous period, in the period 2019-2020, Estonia, Iceland, Lithuania, Malta and Slovenia had a change in total factor productivity in the direction of increase and no change was found for Latvia. In all other periods, no productivity growth has been determined in the countries subject to review. According to the results of the analysis, the highest TFP average for the period 2012-2020 belongs to Estonia and the lowest average belongs to Germany.

The results obtained from the estimation of the Tobit model, Bootstrap Tobit model and Marginal Effects given in equality (9) by the maximum probability method using the balanced panel data set for the period 2012-2020 are reported in Table 2. 
Relationship between Productivity and Digitalization with Tobit Model Based on Malmquist Index

Table 2. Random effect panel tobit model estimation results

\begin{tabular}{|c|c|c|c|c|c|c|}
\hline TFP & Coef. & Std. Err. & $z$ & $P>|z|$ & \multicolumn{2}{|c|}{ [95\% Conf. Interval] } \\
\hline DIGINC & 0,014379 & 0,0010376 & 13,86 & 0,013 & 0,0123454 & 0,0164127 \\
\hline _cons & $-0,3493842$ & 0,0875779 & $-3,99$ & 0,000 & $-0,5210338$ & 0,1777346 \\
\hline /sigma_u & 0,1590569 & 0,024212 & 6,57 & 0,000 & 0,1116022 & 0,2065116 \\
\hline /sigma_e & 0,0833264 & 0,004237 & 19,67 & 0,000 & 0,0750221 & 0,0916308 \\
\hline Rho & 0,7846532 & 0,0557882 & & & 0,6606132 & 0,8773566 \\
\hline \multicolumn{3}{|c|}{ LR test of sigma_u=0: chibar 2(01) } & 57.77 & \multicolumn{2}{|c|}{ Prb> = chibar 2} & 0.000 \\
\hline \multicolumn{7}{|c|}{ Bootstrap Tobit } \\
\hline TFP & Coef. & $\begin{array}{l}\text { Bootstrap } \\
\text { Std. Err. }\end{array}$ & $z$ & $P>|z|$ & \multicolumn{2}{|c|}{ [95\% Conf. Interval] } \\
\hline DIGINC & 0,014379 & 0,0045792 & 3,14 & 0,002 & 0,005404 & 0,0233541 \\
\hline \multicolumn{7}{|c|}{ Marginal Effects } \\
\hline TFP & $d y / d x$ & $\begin{array}{c}\text { Delta Method } \\
\text { Std. Err. }\end{array}$ & $z$ & $P>|z|$ & \multicolumn{2}{|c|}{ [95\% Conf. Interval] } \\
\hline DIGINC & 0,014379 & 0,0010376 & 13,86 & 0,000 & 0,0123454 & 0,0164127 \\
\hline
\end{tabular}

Notes: Number of observations: 240, Uncensored: 232, Left censored: 0, Right-censored: 8, Number of group: 30, Observations per group: (min: 8, avg: 8.0, max: 8), Log Likelihood: 188.8943, Wald $X^{2}$ (1): 192.05, Prob $>X^{2}: 0.0000$

According to the estimated results obtained, 232 of the 240 observations are uncensored, i.e. the value of the dependent variable (TFP) is below 1 , and 8 of them are censored from the top (right), i.e. the value of the dependent variable is above 1 . According to the Wald statistical value, which is used to test the meaningfulness of the overall model, due to the fact that the probability (prob) value $(0.0000)$ of the Wald value, which exhibits a distribution of $x^{2}$ with 1 degree of freedom, is less than the determined $\alpha$ significance level $(0.01)$, zero hypothesis $\left(\mathrm{H}_{0}\right)$ in the form of "model is generally insignificant" (parameters are insignificant together) is rejected and it is concluded that model is significant at the significance level of $\% 1$. In addition, the marginal effects of the model were calculated. According to the results, it was determined that 1 unit change in DIGINC caused an increase of 0.014379 units on the TFP value.

Table 2 contains, among other results, coefficient estimates, standard errors related to estimates, $Z$ statistics, $p$ values, and $95 \%$ confidence range. It was determined that the coefficient of this variable was statistically significant, and its sign was positive because the values of DIGINC variable $P$, which refers to the digital participation rate of the 30 countries subject to the analysis, were less than the determined $\alpha$ significance level.

\section{CONCLUSION}

Success of firms at the micro level and countries on the macro scale depends on producing more without increasing the use of labor, capital or other inputs. Digitalization is recognized as a new phenomenon affecting the success of companies and countries. This study provides some evidence in terms of the impact of digitalization on TFP. Does an inclusive digitalization, that is, a situation where everyone contributes and benefits the digital world, affect TFP? For this purpose, digital inclusion prepared by Eurostat was discussed and its relationship with TFP was examined in 30 countries for 2012-2020 years. The calculated Malmquist TFP index was analyzed using the Tobit model with the digitalization variable. The results showed that digital inclusion increased TFP. Given the impact of innovation on increasing competitiveness and economic growth, and the rapid spread of digitization on a global scale, the results do not seem surprising. Digitalization is an application for every field. But digitalization is known to have significant heterogeneity within countries or even regions. Not every actor has access to the digital world and the degree to which they are keeping up is to the same extent. Infrastructure investments, especially in underdeveloped and developing countries, need to be completed and various obstacles must be removed. Businesses that have advantages, especially in their field, should come into play and provide a breakthrough within the industry. It is very important that digitalization practices are shared, and investments are made correctly. Because it is inevitable that people will now coexist with technology. In doing business together and jointly, there is a need for policies that will decrease the costs of labor rather than the labor losses and make a quick profit. Trainings should be organized to adapt employees to digitized processes in a short period of time. Digitalization causes stronger ties in production and marketing at the level of international economic relations and the world to become more integrated. For example, the internet allows people to develop new ideas, entrepreneurs and markets, offering high-speed and intermediary-free and end-user-friendly systems to new products outside of specific businesses.

Digitalization should be considered as an interdisciplinary concept that should be studied in multidimensional terms. But the fact that digitalization has started to be investigated over the past few 
decades, especially in terms of measurement methods, causes the data set to be limited to the past. This eliminates the possibility of working with a long data set. In addition, there is a problem that some data has not been available in recent years. For this reason, it is thought that studies on digitalization will accelerate in the coming years due to the development of the data set. 


\section{REFERENCES}

Akaeva, A.A. and Sadovnichiib, V.A. (2021). "The Human Component as a Determining Factor of Labor Productivity in the Digital Economy", Studies on Russian Economic Development, 32(1), 29-36.

Berlak, J., Hafner, S. and Kuppelwieser, V.G. (2021). "Digitalization's Impacts on Productivity: A Modelbased Approach and Evaluation in Germany's Building Construction Industry", Production Planning \& Control, 32(4), 335-345.

Bhatnagar, H. (2017). "Demonetization to Digitalization: A Step Toward Progress", Management and Economics Research Journal, 3, 11-15.

Bilim, Sanayi ve Teknoloji Bakanlığı. (2018). "Türkiye'nin Sanayi Devrimi Dijital Türkiye Yol Haritası", https://www.gmka.gov.tr/dokumanlar/yayinlar/2023_Dijital-Turkiye-Yol-Haritasi.pdf (Accessed Date: 20.07.2021).

Burkett, D. (2017). "Digitisation and Digitalisation: What Means What?" https://workingmouse.com.au/innovation/digitisation-digitalisation-digital-transformation, (Accessed Date: 11.07.2021).

Caves, D. W., Christensen, L. R. and Diewert, W. E. (1982). "Multilateral Comparisons of Output, Input and Productivity Using Superlative Index Numbers", Economic Journal, 92, 73-86.

Cette, G., Nevoux, S. and Py, L. (2021). "The Impact of ICTs and Digitalization on Productivity and Labor Share: Evidence from French Firms", Economics of Innovation and New Technology, DOI: 10.1080/10438599.2020.1849967.

Coelli, T. (1996). "A Guide to DEAP Version 2.1: A Data Envelopment Analysis (computer) Program. Centre for Efficiency and Productivity Analysis", University of New England, Australia, 96(08), 1-49.

Coelli, T. J., Rao, D. S. P., O'donnell, C. J. and Battese, G. E. (2005). "An Introduction to Efficiency and Productivity Analysis", Springer Science \& Business Media, Austrilia.

Corduneana, A. (2018). "Schumpeterian View on Economic Development through Information Technologies", Proceedings of the 9th International Conference of Doctoral Students and Young Researchers, Romania, 78-81.

European Commission. (2021). https://digital-strategy.ec.europa.eu/en/policies/digital-inclusion, (Accessed Date: 15.07.2021).

Eurostat. (2021), https://ec.europa.eu/eurostat, (Accessed Date: 15.07.2021).

Ezrachia, A. and Stucke, M. E. (2018). "Digitalisation and its Impact on Innovation”, European Commisson Working Paper.

Färe, R., Grosskopf, S., Norris, M. and Zhang, Z. (1994). "Productivity Growth, Technical Progress and Efficiency Change in Industrialized Countries", The American Economic Review, 84(1), 66-83.

Gal, P., Nicoletti, G., Renault, T., Sorbe, S. and Timiliotis, C. (2019). "Digitalisation and Productivity: In Search of the Holy Grail Firm-Level Empirical Evidence from European Countries", OECD, Economics Department Working Papers No. 1533.

Habibi, F. and Zabardast, M. A. (2020). "Digitalization, Education and Economic Growth: A Comparative Analysis of Middle East and OECD Countries", Technology in Society, 63, 101370.

Hagberg, J., Sundstrom, M. and Egels-Zandén, N. (2016). "The Digitalization of Retailing: An Exploratory Framework", Int. J. Retail Distrib. Manag., 44(7), 694-712.

Henriette, E., Feki, M. and Boughzala, I. (2016). "Digital Transformation Challenges", MCIS 2016 Proceedings 33 , http://aisel.aisnet.org/mcis2016/33(Accessed Date: 20.07.2021).

Horvat, D., Kroll, H. and Jäger, A. (2019). "Researching the Effects of Automation and Digitalization on Manufacturing Companies' Productivity in the Early Stage of Industry 4.0", Procedia Manufacturing, 39, 886-893.

IEA. (2017). "Digitalization \& Energy", https://www.iea.org/reports/digitalisation-and-energy, (Accessed Date: 11.07.2021).

Jacobsen, C., Sørensen, A. and Junge, M. (2011). "Digitalization and Productivity", Centre for Economic and Business Research, Frederiksberg.

Jeske, T., Wurfels, M. and Lennings, F. (2021). "Development of Digitalization in Production Industry - Impact on Productivity, Management and Human Work", Procedia Computer Science, 180, 371-380.

Katz, R., Koutroumpis, P. and Callorda, R. M. (2013). "Using a Digitization Index to Measure the Economic and Social Impact of Digital Agendas", info, 16(1), 32-44.

Kravchenko, O, Leshchenko, M., Marushchak, D., Vdovychenko, Y. and Boguslavska, S. (2019). "The Digitalization as a Global Trend and Growth Factor of the Modern Economy", SHS Web of Conferences 65, 07004, 1-5. 
Krutova, O., Koistinen, P., Turja, T., Melin, H. and Sarkikoski, T. (2021). "Two Sides, but Not of the Same Coin: Digitalization, Productivity and Unemployment", International Journal of Productivity and Performance Management, 70(2), 427-458.

Leon D. and Meyer V. (2019). "Efficiency Evaluation of Digitalization”, KTH Royal Institute of Technology Information and Communication Technology, Degree Project, Fourth Cycle, 15 Credits Stockholm, Sweden.

Malmquist, S. (1953). "Index Numbers and Indifference Curves," Trabajos de Estatistica, 4, 209-242.

Mammadli, E. and Klivak, V. (2020). "Measuring the Effect of the Digitalization”, The University of Tartu FEBA.

Mankiw, N. G. (2003). "Macroeconomics", Worth Publishers, New York.

Mckinsey Global Institute (2018). "Solving The Productivity Puzzle: The Role of Demand and the Promise of Digitization", McKinsey \& Company.

Metlyakhi, A. I., Nikitina, N. A., Yarygina, L. V. and Orlova, E. O. (2020), "Analysis of the Impact of Economy Digitalization on Labor Productivity in Russia", St. Petersburg State Polytechnical University Journal. Economics, 13(2), 7-17.

Myovella, G., Karacuka, M. and Haucap, J. (2020). "Digitalization and Economic Growth: A Comparative Analysis of Sub-Saharan Africa and OECD Economies", Telecommunications Policy, 44, 101856.

OECD. (2020). "A Roadmap toward a Common Framework for Measuring the Digital Economy, Report for the G20 Digital Economy Task Force”, Saudi Arabia.

Oyeranti, G. A. (2000). "Concept and Measurement of Productivity", http://citeseerx.ist.psu.edu/viewdoc/download?doi=10.1.1.511.9388\&rep=rep1\&type=pdf, $\quad$ (Accessed Date: 29.07.2021).

Pakdemirli, B. (2019). "Dijital Dönüşüm ve Ekonomik Büyüme”, Adıyaman Üniversitesi Sosyal Bilimler Enstitüsü Dergisi, 12(32), 666-694.

Pilat, D. and Criscuolo, C. (2018). "The Future of Productivity What Contribution can Digital Transformation Make?", Policy Quarterly, 14(3), 10-16.

Prokopenko, J. (2005). “Verimlilik Yönetimi Uygulamalı El Kitabı”, (Çev.: O. Baykal, N. Atalay, E. Fidan), MPM Yayınları, No: 476, Ankara.

Savic, D. (2019). "From Digitization, through Digitalization, to Digital Transformation”, Online Searcher, 43, 36-39.

ŞengüL, Ü., Shiraz, S.E. and Eren, M. (2013). "Türkiye'de İstatistiki Bölge Birimleri Sınıflamasına Göre Düzey 2 Bölgelerinin Ekonomik Etkinliklerinin DEA Yöntemi ile Belirlenmesi ve Tobit Model Uygulaması", Yönetim Bilimleri Dergisi, 11(21), 75-99.

Solow, R. M. (1956). "A Contribution to the Theory of Economic Growth”, The Quarterly Journal of Economics, 70(1), 65-94.

Sturm, J. and Williams, B. (2002). "Deregulation, Entry of Foreign Banks and Bank Efficiency in Australia", CESifo Working Paper, No: 816.

Tobin, J. (1958). “Estimation of Relationships for Limited Dependent Variables”, Econometrica, 26(1), 24-36.

Tone, K. (2004). "Malmquist Productivity Index" Handbook on Data Envelopment Analysis”, Springer, US.

Trască, D. L., Stefan, G. M., Sahlian, D. N., Hoinaru, H. and Serban-Oprescu, G. L. (2019). "Digitalization and Business Activity. The Struggle to Catch Up in CEE Countries", Sustainability, 11(2204), 2-17.

TÜBiSAD (2020). “Türkiye'nin Dijital Dönüşüm Endeksi”, Ofset Matbaacılık Sanayi ve Ticaret A.Ş. (Accessed Date:04.08.2021).

World Bank, https://databank.worldbank.org/source/world-development-indicators, (Accessed Date:11.07.2021).

Yılmaz, Y. (2021). "Dijital Ekonomiye Geçiş Süreci, Ölçümü ve Dijitalleşme Verimlilik İlişkisi”, İstanbul İktisat Dergisi, 71, 2021/1, 283-316. 